\title{
IMPOLITENESS AMONG SLAVES. AN EPIGRAPHIC EVIDENCE FOR INSULTS FROM A GRAECO-ROMAN BILINGUAL CONTEXT OF SOUTHERN ITALY
}

\author{
Paolo Poccetti* \\ Università di Roma 2 "Tor Vergata"
}

\begin{abstract}
A threefold inscription scratched on a tile found in the surroundings of Reggio Calabria, dating back to late 2nd century BCE, evidences for insults addressed to slaves employed in a local pottery. Both context and abusive terms point to a controversy broken out among colleagues within the place of work. The offensive words reveal a GreekLatin bilingualism, in which Latin plays the role of language first learned and used in everyday speeches, as well as the high degree of literacy of slaves, confirmed by similar manufactures with Latin and Oscan inscriptions. Nevertheless, the threefold inscription raises some questions about text cohesiveness and, more importantly, the number of the addressees implied by the sequence of appellatives in vocative case, which is the key point for understanding the text as a whole.
\end{abstract}

KEYWORDS: insults, slaves, epigraphy, Greek-Latin bilingualism, Southern Italy.

* Correspondence to: Paolo Poccetti, Università di Roma 2 "Tor Vergata", Via Cracovia, 50 (00133 Roma) - poccetti@lettere.uniroma2.it - https:// orcid.org/0000-0002-1885-9425.

How to cite: Poccetti, Paolo (2022), «Impoliteness among slaves. An epigraphic evidence for insults from a Graeco-Roman bilingual context of Southern Italy», Veleia, 39, 157-172. (https://doi.org/10.1387/veleia.22409).

Received: 2021 january 4; Final version: 2021 april 16.

ISSN 0213-2095 - elSSN 2444-3565 / (C) 2022 UPV/EHU

(i) () $\odot$ This work is licensed under a

This work is licensed under a
Creative Commons Attribution-NonCommercial-NoDerivatives 4.0 International License 
Generally insults are considered among the most conventionalised impolite expressions. However, offensive words and impoliteness do not always overlap: impoliteness encompasses broader phenomena than insults and, inversely, insults are not at all times aggressive, but according to circumstances they may hint at affection and familiarity to the addressee. In fact a multiplicity of variables may pragmatically define the real value of an insult, such as social status and mutual attitudes of collocutors, contexts and style registers.

Abundance of abusive expressions, known in antiquity, concerns slave speeches, not only when slaves address each other, but also when a master addresses his slave. It is self-evident that masters are licensed to use more direct and impolite language to their slaves than the opposite. Essentially the main sources of insults as address forms in dialogues, where slaves are involved, are both Greek and Roman playwrights, who to different extent exploit the more or less rude language for theatrical effects and comic purposes.

Nature and frequency of insults, however, are differentiated according to the diverse genres of comic theatre. Notoriously in the ancient Attic comedy (e.g. Aristophanes) slaves speak in a more impolite manner than in the Nea comedy (e.g. Menander). In parallel, among Romans in Terence plays servants use more polite expressions than their counterparts in Plautus plays. Such a difference clearly depends on the style adopted by each author with respect to the target of his audience, so that such a distribution rests on different rhetoric and stylistic strategies of insulting. Amazingly skilful manipulations of reciprocal insults animate dialogues either between slaves or between slaves and lenones (i.e. merchants of prostitutes) in multiple scenes of Plautinian plays (e.g. Persa 407-425; Pseudolus 360-370).

It is important to stress that 'impolite' forms do not mean lack of education, low cultural level or ignorance of their users. Rude and offensive expressions put in mouth of slaves very often result from a remarkable proficiency in language, that enables them to master lexical resources for creating new terms and word-plays. Not rarely both interlocutors recognize their equal capabilities in insulting reciprocally ${ }^{1}$.

In addition, bilingual abilities, frequent in slave environments, give rise to jokes obtained by combining lexemes of both languages familiar to the speakers or to word plays basing on the double meaning of some lexical items common to different languages. Both strategies are frequently displayed by Aristophanes, in the Greek front, and Plautus, in the Roman front. The most striking examples are provided by abusive terms arising from hybrid compounds such Plautinian flagritriba, inanilogista (Lilja 1965, 40) and Aristophanes' $\Psi \varepsilon v \delta \alpha \rho \tau \alpha ́ \alpha \alpha \varsigma$. A considerable part of insults are hapax due to extemporaneous formation of lexical items and improvised word-plays in dialogic contexts. That is why a number of fragments of lost playwrights (e.g. the Sicilian theatre) are known through glosses intended to explain this kind of terms. We may wonder to what extent, however, abusive expressions work as a comic strategy in theatrical plays for featuring slave speeches or they merely mirror a real way of addressing slaves.

\section{EPIGRAPHIC EVIDENCE}

In contrast with the amplitude of theatrical evidence for rude and offensive expressions, epigraphic remains are very scanty, especially in Greek. The most typical examples of impoliteness

1 For instance, as recognised by Pseudolus after an interaction of reciprocal insults: in pertusum ingerimus dicta dolium, operam ludimus (Pl., Pseud. 369). 
noticeable in the Greek epigraphy consist of threat expressions against thieves of personal belongings or tomb violators. But they have no offensive contents and generally belong to a high register.

Unlike the Roman world, no Greek site has provided with a number of graffiti comparable to those scratched on Pompei's walls, among which plenty of abusive expressions are found, even though only a modest quantity occurs as address form. Even more rare are both Greek and Latin inscriptions, that can be surely referred to dialogical interactions between slaves, coloured by reciprocal insults.

In this respect, an exceptional text comes from Pellaro, a site of southern Italy, in the surroundings of Reggio Calabria along the Messina Strait. An inscription scratched on a tile before drying clay, comprises three sections, distributed in different parts of its surface (SEG XXXIX: 1062; D'Amore 2007, n. ${ }^{\circ}$ 58). Following the layout of writing on each line, the main editions and commentaries presented the epigraphic sections as follows (Fig. 1):

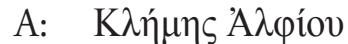

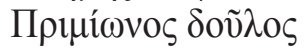

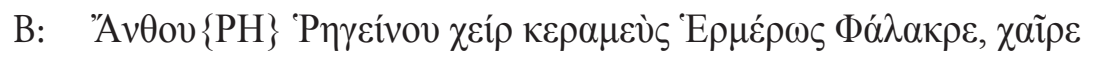

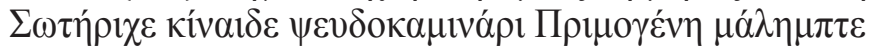

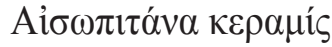

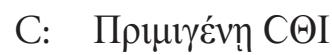
TA $\tau \tilde{\omega} \mu \alpha \lambda \eta \dot{v} \pi$
$\tau \omega$ КАТТАГ

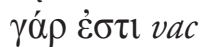
Прнио

As to lettering, the first section (A) clearly differentiates from the other ones, so that it seems to have been written by a different hand. Undoubtedly the section (A) displays the most accurate script, shown by the very regular and bold shape of letters in cursive style and text layout in the centre of the tile surface. In contrast the sections (B) and (C) show an increasing degree of inaccuracy: (B) is featured by an erroneous syllabic repetition and an ambiguous wording, that enables alternative readings; $(\mathrm{C})$ is syntactically uneven and undeniably unaccomplished, as proven by the

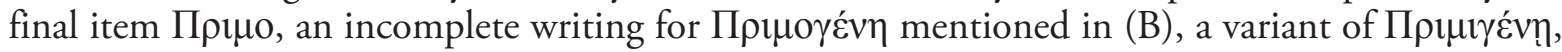
the initial word of $(\mathrm{C})$.

Since its publication the threefold inscription has been interpreted as an abusive invective (B) emphasized in (C) against a dead person, mentioned in (A) (Mosino 1989; 2002; Consani 1995). According to this view, the tile would be formerly conceived for a funerary context, as

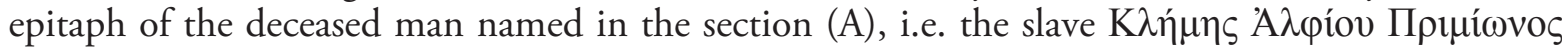
$\delta o v ̃ \lambda o s$. The following sections (B) and (C) would have been secondarily added by somebody, possibly another slave, for derogatory and disparaging purpose against the deceased colleague. It is self-evident that the derogatory texts (B) and (C) should have been drafted almost simultaneously with the epitaph (A) and scratched on the tile during the lapse of time between moulding and firing clay.

This view in itself assumes a rather unusual practice of denigrating a deceased, aiming to commit a negative assessment of an individual to the enduring memory of his sepulchral monument. Such a conclusion, however, is insufficiently corroborated by finding circumstances. According to archaeological reports, the tile was placed inside the tomb at a later date than the burial itself. More precisely the tile was found in a filling layer, after the tomb was violated: this detail conveys 
the impression that the item resulted from a brickyard dump. In other words, the inscribed tile was reused, so that no relationship can be established between the context of finding and the contents of the text.

In addition, the inscribed surface was unearthed in a reversed position, so that the inscription was invisible to anybody. To sum up, the tile seems to have been reused in relation to the context where it was brought to light. As a result, any primary connection between the inscriptions and finding context of the tile seems to be excluded. In conclusion, neither the finding circumstances nor the text in itself evidence for the original function of (A) as sepulchral inscription, so that an alternative explanation is needed.

The fact that any section of the inscription and finding circumstances are reciprocally unrelated has repercussions on both chronology and text interpretation. As to chronology, the dates, so far suggested, range from $3^{\text {rd }}$ century $\mathrm{BC}$ to $1^{\text {st }}$ century AD. However, on the one hand, the earliest date, connected to the original setting up of the burial (Consani 1995), is to be excluded by the reuse of the tile after violating the tomb and, on the other hand, the latest chronological term, basing on lettering (Buonocore 1991-92, 231), is purely speculative. Consequently, an intermediate date around late $2^{\text {nd }}$ and early $1^{\text {st }}$ century BCE (Lattanzi 1989, Lazzarini 1989) seems to be more reasonable and consistent with both epigraphic and linguistic data.

\section{TeXt COHEsiveness}

Firstly, an important factor, that points to text cohesiveness arises from the circumstance that all parts of the threefold inscription were achieved in a short time span between shaping the artefact and firing clay. Hence, they were drafted almost simultaneously by individuals operating in the same activity and the same production process. All that points to extemporary pieces of writing performed by workers in a moment of their activity within a brickworks.

Two different hands are responsible for $(\mathrm{A})$ and $(\mathrm{B}) /(\mathrm{C})$ respectively. The distinction between $(\mathrm{A})$ and $(\mathrm{B}) /(\mathrm{C})$ is shown by differences in nature, contents, shape of letters and layout of writing.

Further clues for text cohesiveness are supplied by lexical units linking the diverse parts of the inscribed tile. Among them the most essential one is the mention of individuals indicated as slaves.



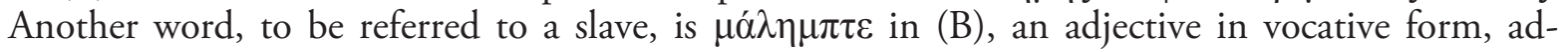
dressed to a person different from the individual mentioned in (A). Má $\lambda \eta \mu \pi \tau \varepsilon$ is a compound, formed by joining two Latin terms (i.e. male èmptus), whose literal meaning "badly acquired", that is "result of an unsuccessful acquisition or bargain" refers to the practice of slave sale, as human merchandise, extremely widespread in the Roman world. Pragmatically, its value "bad, worthless, unhelpful", addressed to a person, is an insult, that parallels expressions occurring in theatrical plays for denoting incapable or inefficient persons, e.g. Latin nihili, minimi pretii (Lilja 1965, 22). Repetition of this word in dative case $(\tau \tilde{\omega} \mu \alpha \lambda \eta \dot{\eta} \nu \tau \omega)$ in (C) and, more importantly, in the same

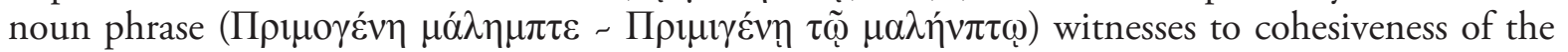
sections $(\mathrm{B})$ and $(\mathrm{C})$.

Mentions of slaves occurring in every section of the inscribed tile depict a slave environment, which contribute to define the argumentative structure of the text as a whole. The fact that slaves were responsible for the writing is consistent with the context, given that individuals of this social status conform to the common standards of the workers employed in brickyards and pottery factories during the Roman period. 
It is not surprising that slaves wrote on their manufactures. The average level of their literacy is signalled by both literary sources and epigraphic evidence. More frequently they formally sign their artefacts, as shown, in Latin epigraphy, by the late-republican pottery from Cales (e.g. CIL I ${ }^{2}$ 412a,b; 413). Noteworthy uniquely Roman nomenclature enables to distinguish slaves from freeborn men, due to the use of the term servus, shortened $s$. unlike other naming systems, such as the Greek and Oscan ones, that generally omit the terms for 'slave', in parallel to those for 'son'. Furthermore high literacy level acquired by slaves is manifested by informal and playful inscriptions or jokes made on manufactures not immediately visible, such as roof tiles. The commonest contents of this kind of inscriptions are personal names, that mostly work as signatures aiming to mark a personal identity, given that freedom of expression was rather restrained among slaves.

Regarding the type of support and circumstances of writing, the most striking parallel to the inscribed tile from Pellaro is provided by a tile from Pietrabbondante, an important settlement in the heart of Samnium, where a quantity of Oscan inscriptions have been unearthed. In the Samnite tile a twofold inscription has been scratched before drying clay by a pair of women slaves of the same owner, which employed them in his local brickworks (ImIt 1186; CIL I² 3556a). Inscriptions were explicitly conceived as signatures of both individuals, who used language and alphabet more familiar to each of them, i.e. Latin and Oscan respectively, for manifesting their identity through their respective signature (Adams 2003, 124; Estarán 2016, II, 17-21).

As to the inscribed tile from Pellaro, nature of a signature is likely to be recognized in the section, (A), where a single name in nominative without any syntactic structure is positioned in the

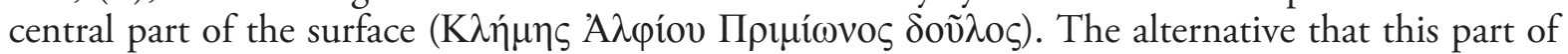
inscription was conceived as an epitaph is excluded by archaeological reasons, as said above. Remarkable accuracy, regular shape and considerable dimension of lettering give the impression of a somewhat showy and boastful training in script.

An essential fact, however, differentiates the pair of inscriptions on the Pietrabbondante tile from the threefold inscription on the Pellaro one. The former results from an agreement between two women slaves, who harmonize in putting their signatures, each of them in her own language and alphabet, but in a symmetric way. The latter, in contrast, reveals a disagreement, which is manifested by the derogatory expressions addressed to individuals capable to read those messages Consequently the addressees cannot be anybody else than colleagues employed in the place of work, where the tile was manufactured.

A clue for the origin of the controversy among colleagues playing an active part in the pottery is provided by a term, addressed as an insult ( $\psi \varepsilon v \delta о \kappa \alpha \mu \iota v \alpha ́ \rho \mathrm{l})$, referring to laziness or negligence related to specific tasks of the job itself.

\section{BILINGUALISM AND INSULTS}

A striking feature common to both inscribed tiles from Pietrabbondante and Pellaro is the multilingual and multicultural literacy of slaves employed in manufacturing tiles: on the one hand, Oscan and Latin in the heart of ancient Samnium (Adams 2003, 124; Estarán 2016, II, 17-21; Poccetti 2020), on the other hand, Latin and Greek in the district of the Messina Strait (Consani 1995).

As recognized since its finding, the language of the inscribed tile from Pellaro is a mixture of Greek and Latin. Notoriously the concerned region, named ager Bruttius by Romans and today Calabria, as a whole, was characterized by a widespread and deep-rooted Greek-Latin bilingual- 
ism, carrying on the previous Greek-Oscan bilingualism (Poccetti 1988), for which this area was renowned in the early Roman period (e.g. P-Fest. 31 L. = Enn., Ann. 496 V.; Lucil. 1124 M.). An onward unbroken continuity is currently shown by the considerable impact of Greek on the local Romance dialects as well as by the survival of Greek speaking communities until today.

There is manifold evidence for blending of Greek and Latin in every epigraphic section of the

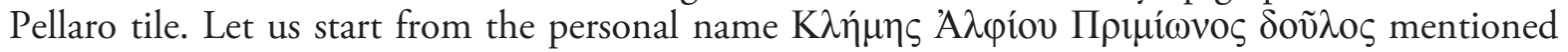
in (A). The naming system in itself conforms to Roman patterns. A Latin influence is revealed by the term $\delta$ oṽ $\lambda$ ऽ, which is uncommon in Greek slave names, in parallel to the term vió $\varsigma$ 'son' for freeborn men. Significantly a massive rise of occurrences of both terms is observable in Greek epigraphy of the Roman period.

The formula, as a whole, imitates the Roman system of naming slaves, normally constituted by the personal name of the individual, followed by a two-member name of his master and the abbreviated term for slave, e.g.: Pilemo Helvi A. s. (CIL I² 681), Bargates Epidi M.s. (CIL I² 2696).

Each member of the formula is also relevant to the Roman nomenclature. K $\lambda \eta^{\prime} \mu \eta_{\varsigma}$ is a rendering of the spoken form of Clemens, numbered among the most common names of slaves. His master bears a two-member name: 'A $\lambda \varphi 10 \varsigma$, a nomen gentilicium of pre-Roman origin, occurring in two Oscan inscriptions from the same region (ImIt 1475-1478) and Прциív, a hybrid cognomen, combining Latin Primus and the Greek morpheme -í $\omega v$, originally indicating descendants, such as Oủpaví type of derivatives from Latin numerals is confirmed by $\Sigma \varepsilon \kappa o v v \delta i \omega v$, attested in Rhegium and Locri (D’Amore 2007, n. ${ }^{\circ}$ 58; Del Monaco 2013, n. ${ }^{\circ}$ 114).

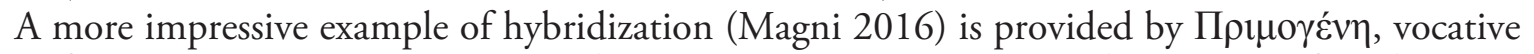

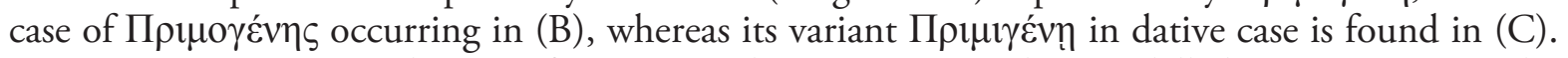

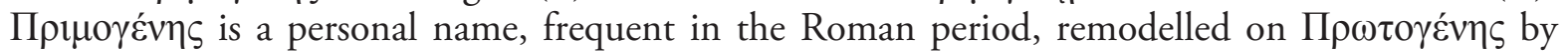

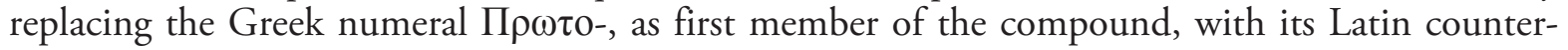


the hybrid name, which is recorded in Sicily and elsewhere since the Imperial period. Notewor-

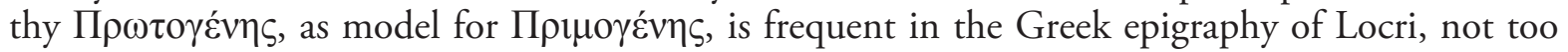
far from Pellaro. Its Latin transcription occurs in the earliest Latin inscriptions, as shown by the metrical epitaph of Protogenes, a theatrical actor of Greek origin, deemed contemporary with the Ennius'life (CIL I² 1861; ILLRP 804). Most importantly Protogenes, like its abbreviation Protus, is one of the commonest names of the Roman slaves, as proven by their frequency among cognomina of freedmen together with their Latin respective translations Primigenius and Primus (Kajanto 1965, 18, 77; Solin 1971, 107; 1982, 141-143; 180).

In fact, Primigenius, as personal name, could even imply a double meaning, if related to the Latin adjective primigenius "original, primeval". In this sense the adjective is used as epithet assigned to the goddess Fortuna Primigenia (Champeaux 1975, Franchi De Bellis 2014). In this case, the fact that the epithet of Fortuna is recorded by the earliest votive inscriptions specifically connected with the local worship typical of Praeneste seems to exclude a Greek influence. In turn,

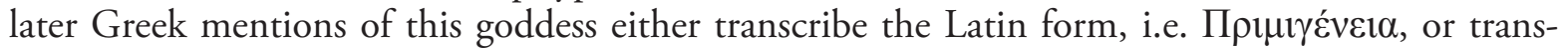

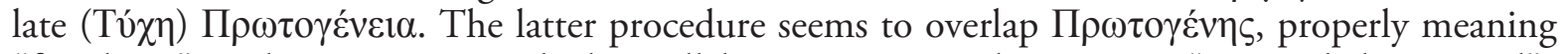
"first-born", with $\pi \rho \omega \tau$ ó ${ }^{\circ}$ ovo, which parallels primigenius in the meaning "primordial, primeval".

An intersection of those values is likely to have affected personal names particularly in a bi-

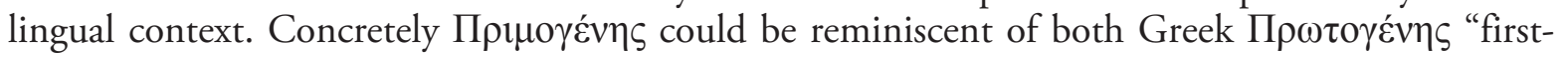

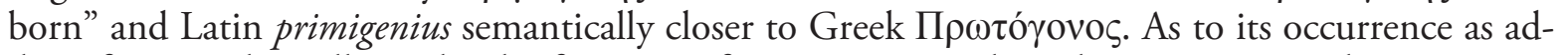

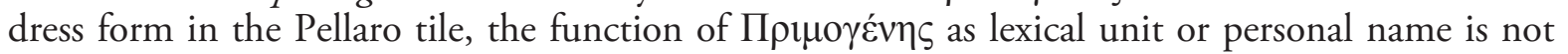


clearly distinguishable, due to the different ways of interpreting the text in the section (B), that

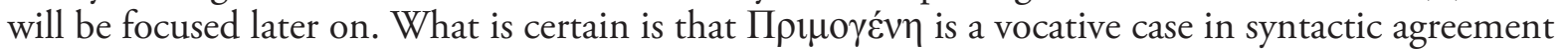

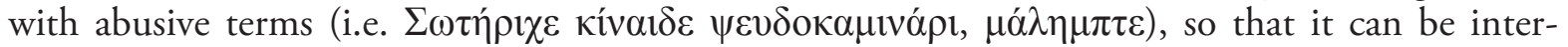
preted either as a name of the addressee himself or as an expression intended to increase intensity of the insults.

Now let us examine the abusive terms, whose offensive function is manifested by their occur-

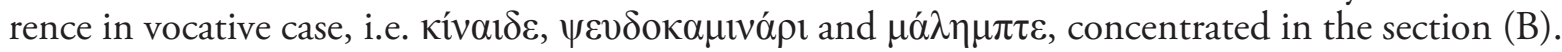
Significantly each of them immediately reflects remarkable effects of the Latin-Greek bilingualism.

Kívalde is a Greek word passed in Latin at least since Plautus time, to which its earliest occurrences in Latin date back. More likely, the Greek loanword arrived in Latin prior to literary authors of $2^{\text {nd }}$ century BCE, considering its common use in Plautus and Lucilius. The original descriptive value referring to male actors or dancers with effeminate habits, recorded by a Nonius' glose $^{2}$, is preserved by both Plautus ${ }^{3}$ and Lucilius. Hence the offensive meaning arises from its use as address form making a direct allusion to homosexual behaviour of an individual. Generally, vocabulary related to sexual habits gives rise to the most popular and vulgar types of rude expressions in any time when insulting somebody (Opelt 1965, 155; Lilja 1965, 68-70; Adams 1982, 200).

The Greek origin of the Latin term for homosexual people parallels a similar phenomenon noticeable in modern languages, as shown by the widespread use of the English term "gay" in the western European languages (e.g., Spanish, French, Italian, German). In turn, the English term, arising from Medieval French, parallels to some extent the semantic evolution of the Greek term from "bright, showy" to "uninhibited by moral constraints" with sexual connotation. In Greek

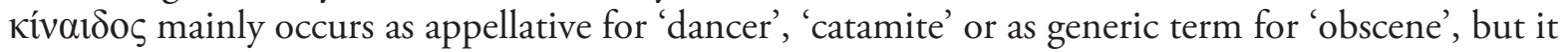
is very rare and unusual as address form, as confirmed by its almost unknown use in vocative case (Opelt 1965, 123; Adams 1982, 200).

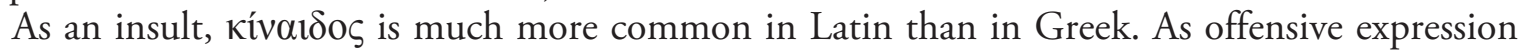
suitable to diverse contexts and occasioned by different reasons, cinaedus presents numberless occurrences in both Latin epigraphic and literary sources. In Plautus its use as address form, signalled by the vocative case (cinaede), figures besides the descriptive value, indicated by different syntactic structures. In a Plautinian occurrence, cinaede is accompanied by an epithet, that emphasises an effeminate habit of an individual in order to intensify its abusive force (cinaede calamistrate: Pl., As. 627).

A remarkably higher frequency of cinaede as address form in vocative is found in Catullus' poetry, as aggressive expression for attacking different persons. Diversity of reasons, underlying the verbal attacks, points out a shifting from a denotative (or cognitive) meaning to a connotative (or emotive) function, which is confirmed by the comparative cinaediorem, referred to a woman

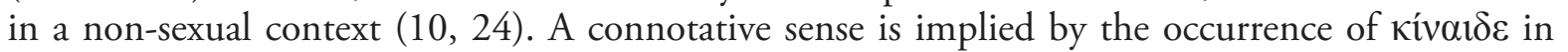
the Pellaro tile like its use by Catullus. Furthermore, the Catullian expressions, i.e. cinaede Furi $(16,2)$, cinaede Thalle $(25,1)$, cinaede Romule $(29,5)$, cinaede fili $(33,3)$, closely parallel the noun

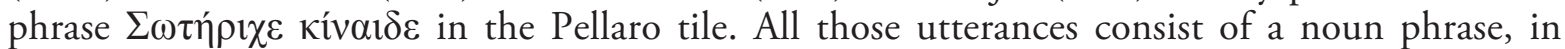

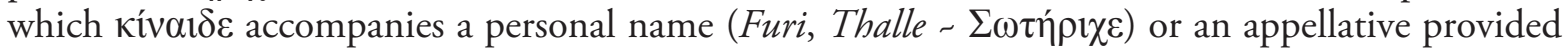
with identifying function (Romule, fili). The syntactic order, however, is inverted in $\Sigma \omega \tau \eta \dot{\rho} \rho \iota \varepsilon$

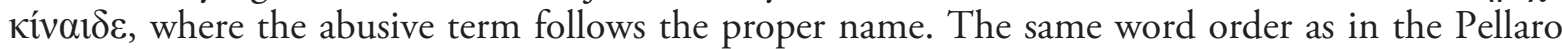

\footnotetext{
2 Non. 5: cinaedi dicti sunt apud veteres saltatores vel

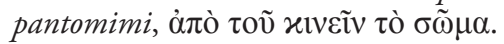

3 Pl. Mil. 668:ad saltandum non cinaedus malacus aequest atque ego. 
tile is found in Pompeian graffiti both in address form (vocative case) and in descriptive utterances (Wachter 2019, n. 1156, 1349, 1350, 1351, 1352). All those occurrences show that cinaede, when accompanying a personal name, simply work as abusive and derogatory term, not necessarily referring to sexual behaviour, like English 'nancy' or 'fairy'.

To sum up, kívaıbos / cinaedus was common to the lexica of both Greek and Latin at the date, which the inscribed tile belongs to. In Greek, however, the word displays uniquely a cognitive or denotative meaning, whereas in Latin an emotive or connotative function is increasingly developed, as shown by its frequency as disparaging term for addressing somebody. The extended use

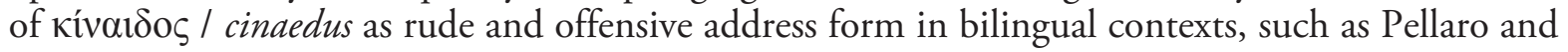
Pompei, reveals that Latin was much more familiar to the speaker especially in colloquial speeches of low register.

The role played by Latin as L1 is confirmed by further impolite expressions occurring in the

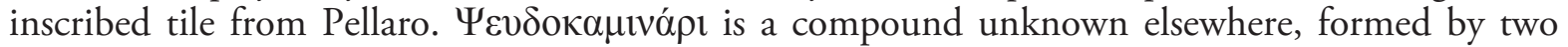

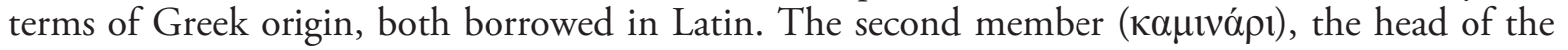
compound, is a derivative from caminus, a Greek loanword (אó $\mu 1 v o \varsigma)$, whose occurrence in Cato indicates an earlier date of the borrowing. This derivative rests on a Latin morpheme -arius, frequent in professional qualifications, such as (faber) lignarius, ferrarius, argentarius, and so on. Caminarius, however, is never attested in Latin, where its synonyms furnarius and fornacarius are found. On the other hand, the Latin morpheme -ario- passed in Greek since late Hellenistic period, as a consequence of the innumerable loanwords from Latin, indicating partly a job activity

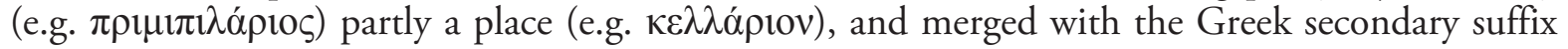
-ápios / -ápiov. The latter originated from combining $-\alpha \rho+10 v$ (Chantraine 1979, 74), with di-

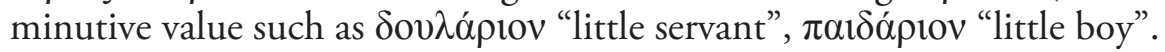

That is why the productiveness of -ápıos / -ápiov increased over time in late Greek and during the Byzantine age until modern Greek, that presents many - $\alpha \rho \iota \varsigma$ derivatives even in personal names. Not rarely the origin of those derivatives is indistinguishable, as shown by $\sigma \tau \alpha \tau \alpha \rho 10 \mathrm{~V} / \mathrm{sta-}$ tarium "slave market", a word circulating amongst Greek and Latin bilingual environments of the eastern Mediterranean area since $2^{\text {nd }}$ Cent. BC (Poccetti 1985).

Interestingly, the diminutive value of -áptov, when referring to individuals, may convey a dis-

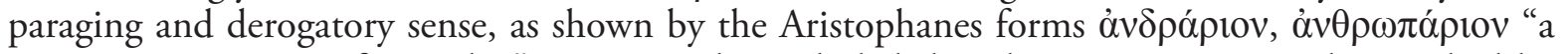
nonentity, a person of no value". It cannot be excluded that the same sense was also implied by

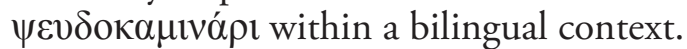


firms its role as language more commonly used by the speaker. The pattern of compounding, however, is Greek, in that it is modelled on several compounds attested since Classical Greek (e.g. $\psi \varepsilon v \delta \delta ́ \mu \alpha v \tau \imath \varsigma, \psi \varepsilon v \delta o \mu \alpha ́ \rho \tau v \varsigma)$, where $\psi \varepsilon v \delta o-$ as first member, works as the adjective $\psi \varepsilon v \delta \eta ́ \varsigma$ meaning "false, deceitful" (Blanc 2018, 62). The disparaging meaning of the lexical base $\psi \varepsilon v \delta$ - is also proven by its opposite term formed by the negative prefix $\alpha$-, when putting in comparison $\psi \varepsilon v \delta o ́ \mu \alpha \nu \tau \imath \varsigma$ "false diviner" and $\alpha \psi \varepsilon v \delta \delta$ $\mu \alpha v \tau \imath \varsigma$ "truthful diviner". The appreciative and admiring value of the negative form $\alpha \psi \varepsilon v \delta$ - in the meaning of "blameless, irreproachable" as opposite to $\psi \varepsilon v \delta$ - is also confirmed by its occurrence in several personal names, such as 'A $\psi \varepsilon v ́ \delta \eta \varsigma, ~ A ै \psi \varepsilon v ́ \delta \omega v$, Аै $\psi \varepsilon v \delta \omega ́$.

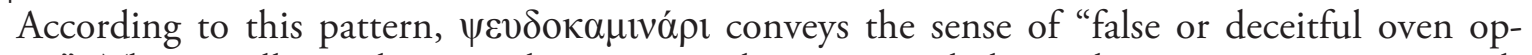
erator". This appellation hints at the reason and context underlying the aggressive utterance addressed to a person appointed to an oven for drying clay manufactures in the pottery at issue. The person is addressed by attributing him the blame for laziness or incapability in carrying out his 
own job. This behaviour is likely to have had repercussions on the work chain and productivity of the pottery, so that it provoked an angry reaction of job colleagues. Probably it is another slave rather than his master or the owner of the brickworks, who shows his irritated face against a lazy colleague. A master is likely to have not confined his reaction to a written rebuke, but to have inflicted a harsh corporal punishment. Various address forms, used in theatrical scenes (Lilja 1965, 54) refer to whipping and other torture (e.g. mastigia, verbero, furcifer), inflicted to slaves. Frequently, characters of slaves in Roman plays are confronted with allegations of deliberate inactivity, laziness and negligence in their jobs, as shown by the offensive terms, such as ignave / ignavissime, iners, piger, lente, nequam/nequissime, more frequently used by their respective masters for addressing them (Dickey 2002, 183).

A dissimulated laziness indeed is not far from a deception. Accordingly, deceitful slaves are recurrent characters in plots of theatrical plays in antiquity and frequently this sort of characters is sketched by their inclination to cheating. Figures of allegedly mendacious and dishonest slaves often occur especially in Latin comedy, where allegations, more or less founded, of deception are disputed between a master and his slave or by slaves each other, so that this kind of debate forms recurrent themes of cues in theatrical dialogues. In this respect, a number of abusive terms referring to deceitful or cheating behaviour are used as address form in several scenes of Roman plays, such as perfide, infide, subdole, false, fallax.

The most typical and renowned figure of cheating and dishonest slave is embodied by Pseudolus, the protagonist of the homonymous Plautinian comedy, whose name is based on the lexical series of $\psi \varepsilon v \delta o-$. More exactly Pseudolus is a hybrid derivative combining the Greek lexeme with

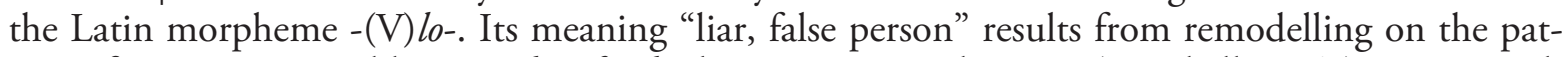
tern of nomina agentis like querulus, figulus basing on Latin lexemes (Zucchelli 1969). Even tough $\psi \varepsilon v \delta$ o- compounds are rare in Latin of the Republican age, the name of Pseudolus reveals that Romans were familiar with the Greek lexeme, as confirmed by the preservation of the vowel -o-, in-

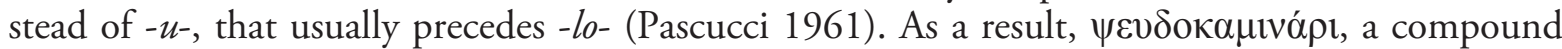
created within a bilingual context, could be easily understood by any speaker of each language at issue.

To sum up, $\psi \varepsilon v \delta о к \alpha \mu \iota v \alpha ́ p l$, as an insult, depicts two deviant and undesirable behaviours of an individual within a working place, that are, on the one hand, his incapability of doing a job and, on the other hand, his attitude to deception and inclination to dissimulate.

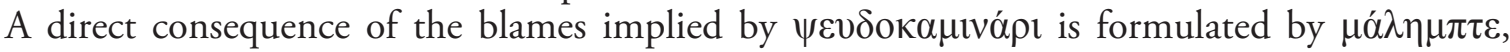
that portrays an individual as an unsuccessful purchase, a bargain ended in failure, in one word "bad" or "worthless". This compound, elsewhere unknown, originated by joining two Latin words, i.e. male emptus, that occur as verbal phrase, but never as offensive address form. Word formation is modelled on the pattern of Latin adjectives like malevolus/benevolus, maleficus/beneficus, basing on a verbal root (Lindner 1996, 108-109), but not on a past participle, as it happens in male émptus $>\mu \alpha \dot{\lambda} \lambda \mu \pi \tau \varepsilon$.

The compound, occurring in vocative case $(\mu \alpha \dot{\alpha} \lambda \eta \mu \pi \tau \varepsilon)$ in (B), is repeated in dative case $(\mu \alpha \lambda \eta v v \pi \tau \omega)$ in $(C)$, that shows its use as both address form and descriptive term. In both occur-

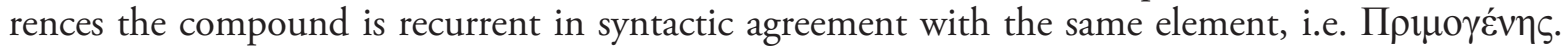
Word repetition is an essential clue for text cohesion, that points to a clear connection between the section (B) and (C), as said above. A further mark of text coherence is provided by the article

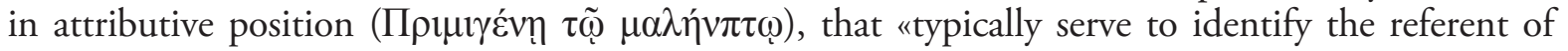
the head noun» (Van Emde Boas, Rijksbaron, Huitink \& De Bakker 2019, 331). In other words,

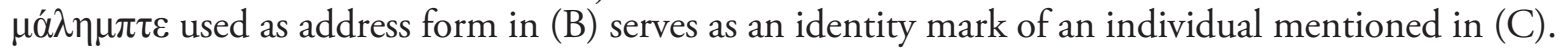


Linguistically, formation of this compound manifests the high proficiency in Latin, that confirms its role as first language acquired and mastered by the speaker. Univerbation of two distinct words gave rise to a phonological restriction, noticeable in the Latin variants of this kind of compounds, like malivolus and malificus instead of malevolus and maleficus, even reflected by their derivatives, such as malificentia, benificentia besides maleficentia, beneficientia. This phonetic treatment in $\mu \alpha{ }^{\prime} \lambda \eta \mu \pi \tau \varepsilon$ is signalled by the grapheme $\langle\eta>$, that in late Hellenistic period is more likely

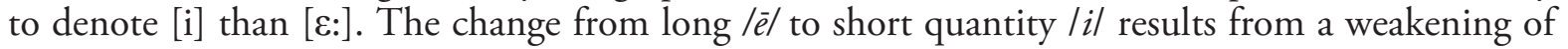
the vowel in the middle syllable after accent shift in the compound (Probert 2006, 282). According to Greek prosodic rules, an outcome of an endocentric compound is a recessive accent, that in the specific occurrence overlaps with the feature typical of the vocative case (Probert 2006, 299). Therefore a phonetic transcription of $\mu \alpha \dot{\alpha} \eta \eta \mu \tau \varepsilon$ seems to be more appropriate ['malimpte] than [ma'le:mpte].

A synchronic variation of the vowel in the middle syllable, shown by alternating spelling of

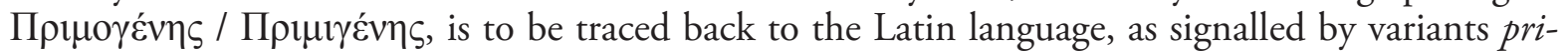
migenius / primogenius; Primigenia / Primogenia (CIL I² 60; 1445; 2531), even observable in transcriptions of the Greek personal name like Protogenes (CIL I ${ }^{2} 1861$ ) and Protigenes (CIL I ${ }^{2} 2864$ ), both in Republican age.

Owing to its basic meaning, male èmptus was suitable to both things and slaves, as signalled by an occurrence of male émptus in Plautus referring to a house, whose purchase resulted to be disappointing or unsatisfactory (Pl., Most. 799). The literal meaning of èmptus with reference to a servant is conveyed by a different expression, i.e. male conciliate, that occurs in a Terence play for addressing the protagonist eunuch Dorus, who entitles the play itself: Exi foras, sceleste! At etiam restitas, fugitive? Prodi, male conciliate! (Ter., Eun. 669; Dickey 2002, 175; 339). This occurrence parallels the Pellaro tile, in that the same concept, formulated by different expressions, occupies the final position of two sets of three abusive terms, addressed to distinct individuals respectively.

A sequence of three insults is not rare in abusive speeches, given that an emotional state is naturally implied by an aggressive talk, which is required to maximize its effect (Hofmann 1980, 216). For this purpose, a threefold insult increases the force of an offensive utterance. Theatrical dialogues exploit the intensifying force of a threefold insult, as shown by two sets of three abusive words, that emphasizes an address form in an Aristophanes play (Aristoph, Ran. 465: ' $\Omega \beta \delta \varepsilon \lambda v \rho \dot{\varepsilon}$

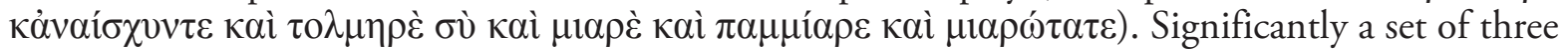
insults is frequently replaced by an abusive term in a compound with the number 'three' indi-

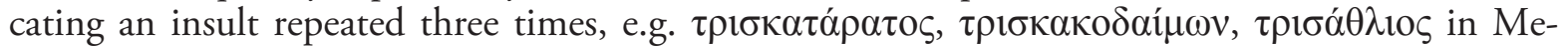
nander (Dickey 1996, 167-172), trifur, terveneficus, triveneficus in Plautus (Miniconi 1959, 166168; Dickey 2002, 176-177). The sequence of three insults is a key point to be taken into account, for interpreting the section (B) of the inscribed tile from Pellaro.

\section{WHAT IS BEHIND THIS TEXT?}

Evidence for three insults, concentrated in the section (B), raises diverse problems concerning their function and use in context. First of all, a crucial question is of whether only one or more addressers and one or more addressees are involved in the speech act and, consequently, to what extent they are respectively identifiable in each block of text. In this perspective the inscribed tile from Pellaro is a challenging test for discourse analysis. 
By combining methodical approaches of both narratology and discourse analysis we may distinguish narrator(s) and/or author(s) from actor(s) and, more importantly, addresser(s) from addressee(s). In this respect, also essential is to attempt to outline the plot of the story, revolving around the offensive utterance. As said above, the setting is provided, on one hand, by the circumstances in which the pieces of writing were scratched on the tile and, on the other hand, by the contents of some insults, above mentioned. Both factors converge on the following scenery: a controversy broken out among slaves about working procedures within the pottery, where they were employed.

Narrators are at least two individuals responsible for two parts of writing, which, on graphic grounds, are attributable to distinct hands, that are $(\mathrm{A})$ and $(\mathrm{B}) /(\mathrm{C})$ respectively. Uniquely in the first section (A), the author matches the narrator, who is identifiable, assuming that the name

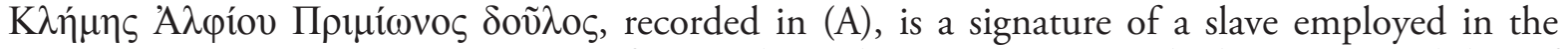
pottery at issue. In contrast, narrator of $(B)$ and $(C)$ does not emerge with clarity. A possibility of

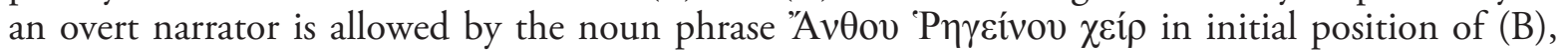
assuming that $\chi \varepsilon i ́ p$ denotes the hand the writer and not that of the craftsman. In the former case

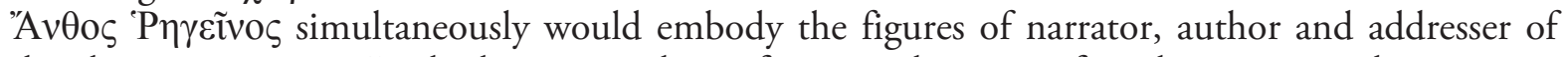
the abusive utterance. In the latter case the craftsman, whose specific role remains unknown, is a

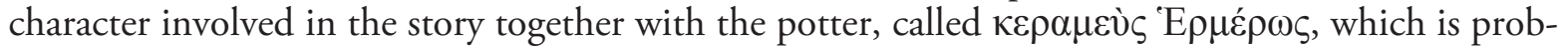
ably the owner of the brickworks.

In this case, a covert narrator should be represented by the concluding expression of (B), the

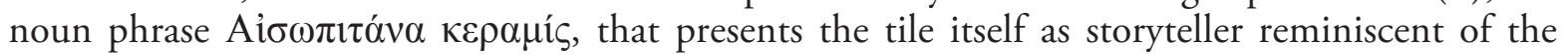

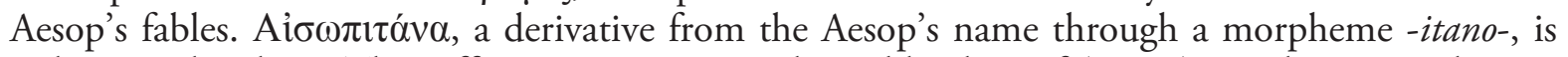
unknown elsewhere. The suffix -itano-, originated as a blending of (Doric) Greek -í $\alpha$ s and Latin -äno- after Romanization of Southern Italy (Pisani 1936; Orioles 1975, 186), is mostly used for ethnic names, such as Neapolitanus, Panormitanus, Lilybitanus (Rohlfs 1985, 97; 104). In con-

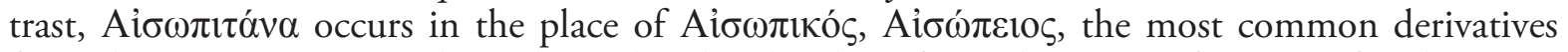
from the Aesop name in Classical Greek. This detail confirms the status of Latin as first language learned by the author and, inversely, his lower level of proficiency in Greek. It cannot be excluded, however, an intentional use of the morpheme -itano-, commonly applied to place names, for portraying the scenario evoked by the inscribed tile as a world inhabited by characters of Aesop's fables. In any event, the mention of Aesop implies the acquaintance with the Aesop's corpus of fables, that evidences for the literacy in the slave environment at issue.

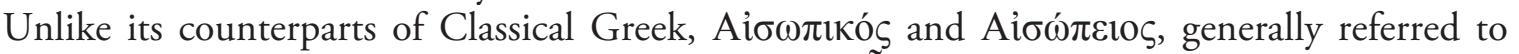

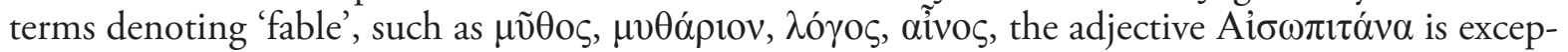
tionally attributed to the word for 'tile', that plays the role of a narrative text. Reasons of the allusion to Aesop are unspecified. Probably they are to be connected to themes of ethics conveyed by the Aesop's tales, whose task was to narrate fictional stories mostly with animal protagonists for educational purposes especially in moral practices. Notoriously behind fiction each tale serves to illustrate a general principle of ethical behaviour to be applied to different events and contexts of the everyday life. That is why the Aesopic corpus of fables provided a solid base for primary education, that yielded a popular heritage without any class differentiation, because their contents involve any aspect of the human life independently of social conditions. In Classical Athens acquaintance with Aesopic tales among common people is proven by the multiple allusions in Aristophanes plays. As to Greek-Roman period we are informed about their use in children's education and as basic exercise in rhetorical schools (e.g. Plut., Mor. 14e 10). The fable contents served also to develop the interpretive capability of the allegorical sense of exemplary stories and to acquire ability to ap- 
ply appropriately general principles of ethical practices to a particular situation (Jedrkiewicz 1987; Zafiropulos 2001).

The mention of Aesop in the inscription of our tile points out not only the educational level of the single slave revealed by the script in itself, but also the knowledge of the Aesop's tales circulating within an environment of workers employed in a pottery. The allusion to Aesop was meant to be referred to specific circumstances and behaviours, well known to the addressees. Consequently the presupposition ensemble enabled them to recognize the behavioural pattern conveyed by Aesop's tales to be related with the situational context. We ignore the specific facts that triggered the reaction broken into insults. However, as said above, the nature of two abusive terms, i.e. $\psi \varepsilon v \delta о \kappa \alpha \mu \imath v \alpha ́ \rho t$ and $\mu \alpha \dot{\lambda} \eta \mu \pi \tau \varepsilon$, that formulate a blame for laziness or conscious negligence relevant to job activities, points to a controversy originated by an imbalanced amount of tasks and inequality of work conditions among colleagues employed in the same place of work. In this scenario the allusion to Aesop is likely to be referred to an ethical norm recurrent in the fable corpus, that is reciprocity (Zafiropulos 2001, 79-97). Reciprocity can be defined as a system of interpersonal and communal relationships that involve mutual obligations between two or more individuals. It is self-evident that imbalance and inequality of work conditions caused by a deviant behaviour or an antisocial habit of colleagues in a place of work prevents teamwork activities and cooperation and obstructs harmony of the communal life. All that transgresses the basic rules of reciprocity underlying any human relation.

\section{ONE OR TWO ADDRESSEES?}

A more complicated issue concerns the long sequence of address forms in vocative case,

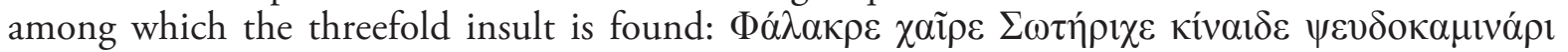

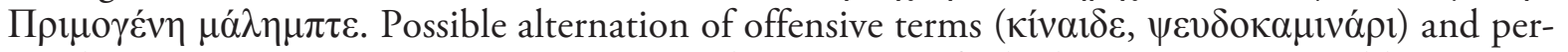

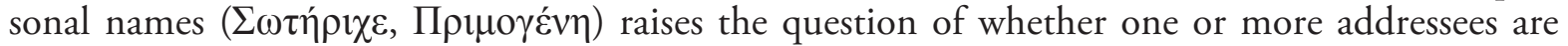
involved. Conflicting factors seem to speak in favour of or against each of these solutions. On the one hand, the verb $\chi \alpha \tilde{i} \rho \varepsilon$ in the second person of the singular points to only one addressee,

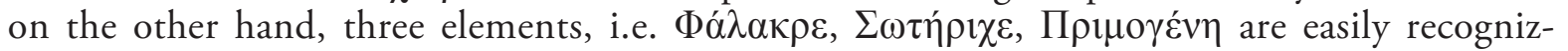
able as personal names, particularly frequent in Southern Italy. More precisely $\Phi \alpha ́ \lambda \alpha \kappa \rho \circ \varsigma$ and

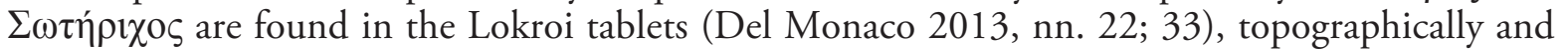

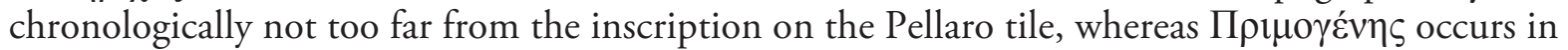

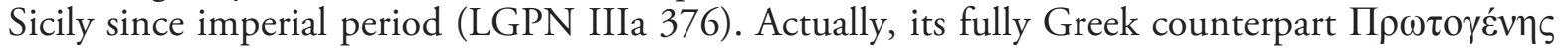

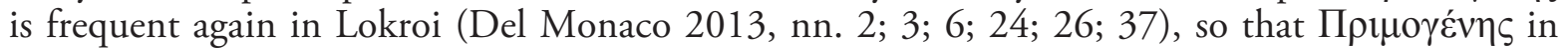
the Pellaro tile can be considered the earliest occurrence of the hybrid compound, so far attested in Magna Graecia.

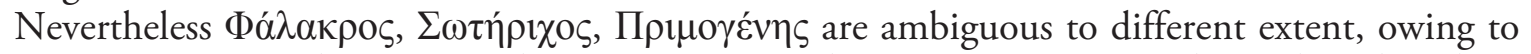
their transparency with respect to lexicon. As personal name $\Phi \alpha ́ \lambda \alpha \kappa \rho о \varsigma$ is identical to the adjective $\varphi \alpha \lambda \alpha \kappa \rho o ́ \varsigma$ "bald" except the usual regressive accent (Probert 2006, 298-300), in parallel to its Latin counterpart Calvus, used as cognomen.

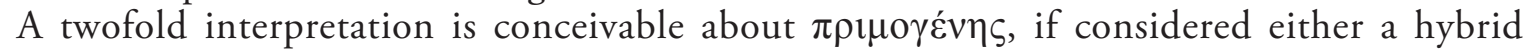
calque of the Latin adjective primigenius meaning "original, primeval” or a Greek personal name partially remodelled on the Latin numeral. To a lesser degree a relation with lexicon is established by $\Sigma \omega \tau$ ńpıðos, so far known only as personal name. According to a purely speculative

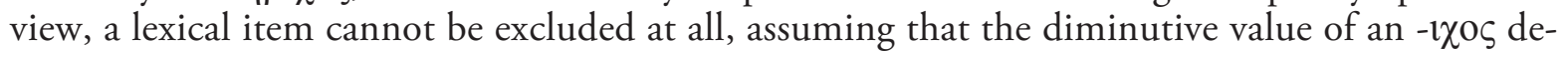


rivative (Chantraine 1979, 404) either shifted to a disparaging sense or was used for ironic purposes.

If all those elements in vocative case are referred to a single person, three interpretive alternatives should be taken into account:

a) All of them are personal names, referring to a single individual. People with multiple names are not rare in the Roman world, even in Greek speaking areas, such as Sicily, distributed in different contexts (Cordano 1997). Individuals provided with multiple names are also known among slaves, as a consequence of changing master.

b) All of them work as lexical items, used with a descriptive function. Thus $\varphi \alpha \lambda \alpha \kappa \rho$ ó $\varsigma$ portrays a physical aspect of the individual as "bald-headed" and $\pi \rho \mu$ o $\gamma \dot{\varepsilon} v \eta \varsigma$ emphasises his primordial impulses to behave outrageously. Less clear is $\sigma \omega \tau \eta \dot{\rho} \chi \chi \varsigma$, , that never occurs as lexical item. According to the above suggestion, this kind of derivative from $\sigma \omega \tau \eta \dot{ } \rho$ could sound something like "petty rescuer or preserver", as derisive and derogatory appellative.

c) The three elements at issue are partially personal names and partially lexemes. Among them $\Sigma \omega \tau$ ípıos is the term, which is more likely a personal name than the other ones for the above reasons and, consequently, it is more easily recognizable as name of the addressee.

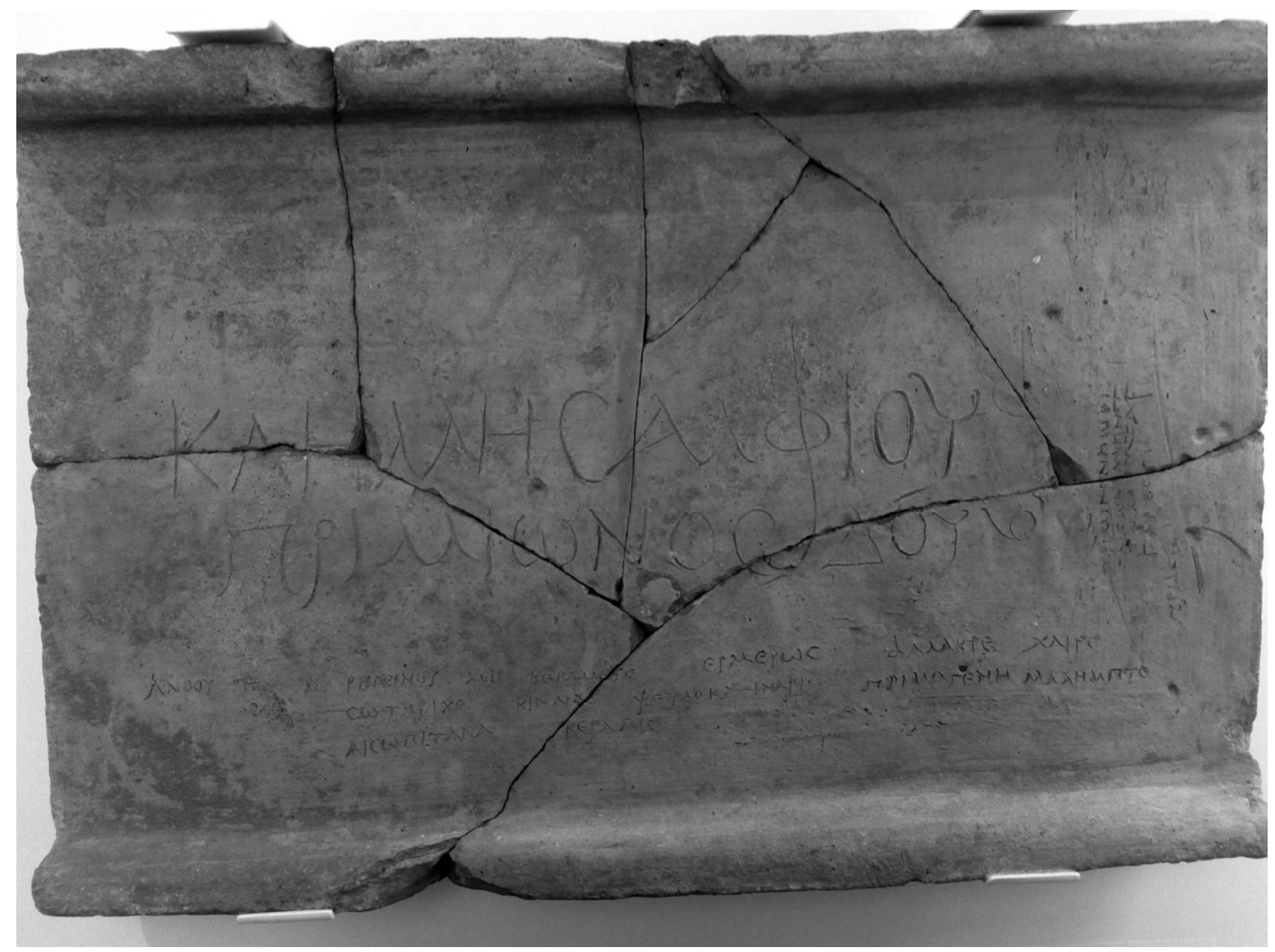

Figure 1. Inscribed tile from Pellaro. 
An assumption of more than one addressee is acceptable only on condition that the series of terms in vocative case is split in two parts. A clue for distinguishing two sets of vocative forms addressed to different individuals is provided by epigraphic rather than syntactic criteria. In the sec-

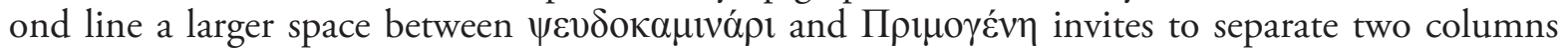

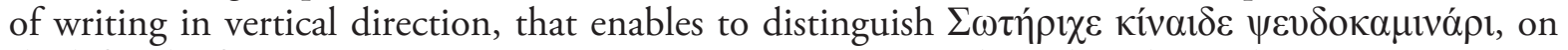

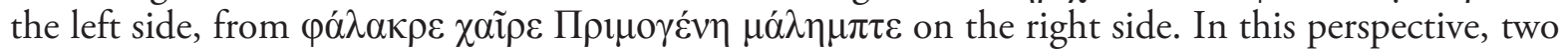
pairs of insults are targeted at two different individuals respectively: on the one hand, a person

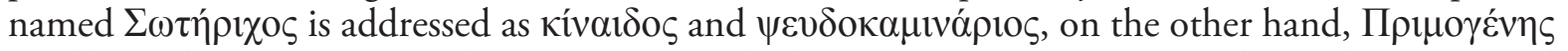

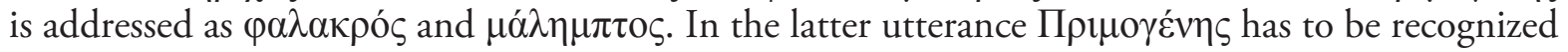

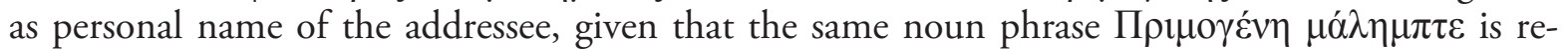

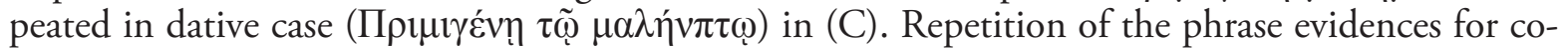

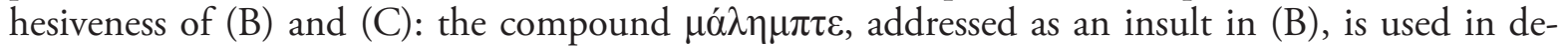
scriptive function for labelling the insulted person $(\tau \tilde{\omega} \mu \alpha \lambda \eta \dot{\eta} v \pi \tau \omega)$.

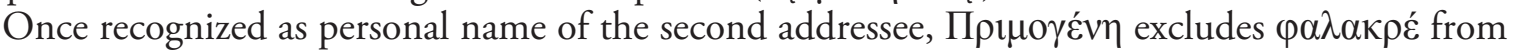
the same function. Nevertheless $\varphi \alpha \lambda \alpha \kappa \rho \varepsilon$, as lexical item, is problematic with respect to both its semantic value and syntactic order, reciprocally related. Following its literal meaning, that is "bald", $\varphi \alpha \lambda \alpha \kappa \rho$ ó $\varsigma$ is to be understood as an attribute portraying a physical aspect of the addressee. We are informed by both Aristophanes ${ }^{4}$ and Plutarch ${ }^{5}$ that bald-headed men were made object of mockery and jests, so that, in this case, the appellative aims to ridicule a physical trait according to a common sense.

When used as address form, $\varphi \alpha \lambda \alpha \kappa \rho \varepsilon ́$ sounds quite impolite in itself, as stressed by a proverb connected to the Aesop's tales, that comments the same expression with a different word order: A $\rho \chi \eta े$

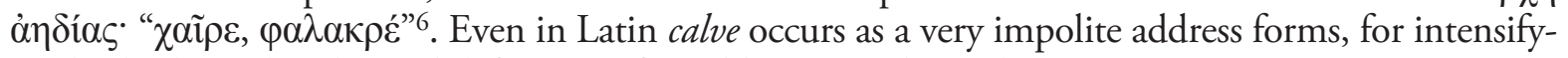
ing both physical and moral deformity of an old man, as shown by a Persius verse ${ }^{7}$. Two occurrences of calve in vocative case are found in the fragments of the Atellanae plays, that witness to a popular way of addressing somebody ${ }^{8}$ : one of them occurs in an angry and aggressive utterance? ${ }^{\text {. }}$

A depiction of a slave as bald-headed may also have a connotative meaning with reference to the acquired or boasted freedom. Shaving head was a symbol of a manumitted slave, who cut his hair before dressing a pilleus, a type of flat hat, that flagged the new status of freedman ${ }^{10}$. If this is the case, we may guess at reasons for adopting the address form at issue in context. An unfair conversion from status of slave into freedman without any merit may have aroused anger among colleagues and provoked such a reaction against him.

In any event, $\varphi \alpha \lambda \alpha \kappa \rho \varepsilon ́$ occurs in predicative position in the syntactic order of the sentence

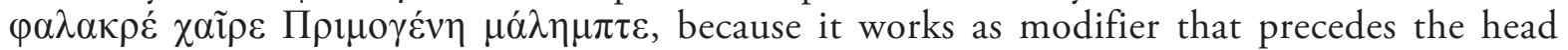


to identify the referent, as confirmed by its repetition with article in the initial phrase of (C), i.e.

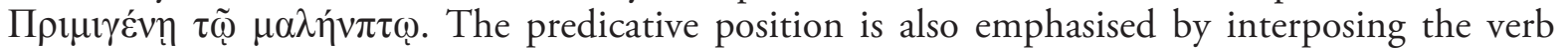
$\chi \alpha \tilde{i} \rho \varepsilon$. The word order in which multiple attributes of an addressee are separated by $\chi \alpha \tilde{\rho} \rho \varepsilon$ is very uncommon. Normally this verb precedes or follows the sequence of diverse terms in polite for-

${ }^{4}$ Aristoph., Nub. 540; Pax 767-771.

5 Plut., Galba 13, 4; Mor. 86b.

${ }^{6}$ Aesopus et Aesopica Scr. Fab., Proverbia 144, 1 (ed. Parry).

7 Pers. I, 56: nugaris, cum tibi, calve, pinguis aqualiculus propenso sesquipede extet.
8 Atell., Pomp. Frg. 118 Frassinetti: quid habes in surpiculi, calve? :: omne piscati genus.

9 Atell., Pomp. Frg. 134 Frassinetti: at te di omnes cum consilio, calve, mactassint malo.

${ }_{10}$ As evidenced in Plautus'Amphitruo 462: ego hodie raso capite calvos capiam pilleum. 


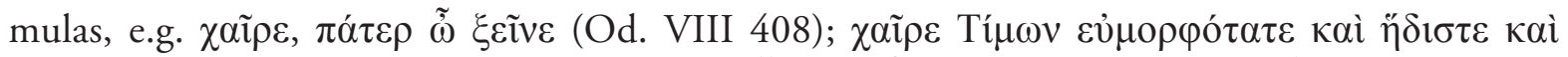

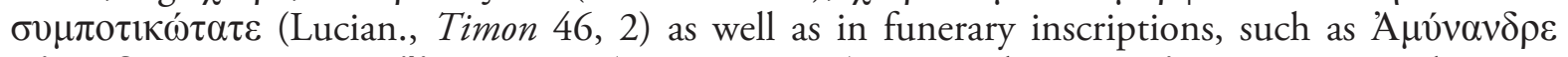

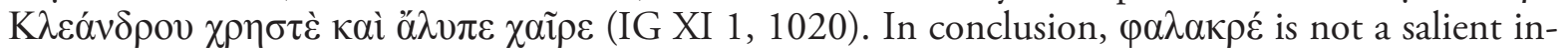

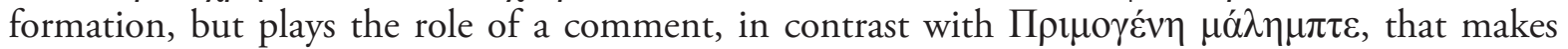
the addressee clearly identifiable within the context at issue.

\section{ConClusion}

The Greek inscription scratched on the Pellaro tile is an exceptional document for diverse reasons. Firstly, as result of an extemporary writing practised by slaves when manufacturing the tile in a pottery. This epigraphic genre evidences for the high level of literacy and cultural training of their authors. Secondly, as a mirror of the Greek-Latin bilingualism, proven by diverse hybrid compounds. Thirdly, as witness to insults and abusive terms used as address forms among slaves, related with controversies aroused for job reasons within their workplace. Fourthly, as epigraphic counterpart of the speech patterns among slaves testified by theatrical plays.

Nevertheless, some crucial problems remain unsolved as to the text interpretation, particularly concerning the number of the addressees of the insults, due partly to syntactic structures partly to ambiguous role of lexical items and personal names. Therefore, this text is a challenging field of discourse analysis, rarely provided by epigraphy.

\section{REFERENCES}

Adams, N. J., 1982, The Latin Sexual Vocabulary, London: Duckworth.

Adams, N. J., 2003, Bilingualism and the Latin Language, Cambridge: CUP.

BLANC, A., 2018, Les adjectifs sigmatiques du grec ancien, Innsbuck: Institut für Sprachwissenschaft.

Buonocore, M., 1991-92, Tradizione ed evoluzione grafico-formale dell'epigrafia greca di età romana nell'area di Rhegium-Locri, in: A. Acconcia Longo, S. Lucà, S.-R. Perria (eds.), Miscellanea di Studi in onore di P.M.Petta. Bollettino della Badia Greca di Grottaferrata N.S. 45, 229-254.

Champeaux, J., 1975, «Primigenius, ou de l'Originaire», Latomus 34, 909-985.

Chantraine, P., 1979, La formation des noms en grec ancien, Paris: Klincksieck.

Consani, C., 1995, «Per la storia linguistica dello Stretto in età ellenistica e romana», in: Scritti linguistici e filologici in onore di Tristano Bolelli, Pisa: Pacini, 193-205 (= 2019, F. Guazzelli e C. Perta (eds.), Scritti scelti, Pisa, Roma: Fabrizio Serra, 229-238).

Cordano, F., 1997, "L'uso greco del terzo nome in Sicilia», in: Atti delle seconde giornate internazionali di studi sull'area Elima (Gibellina, 22-26 ottobre 1994), I, Pisa-Gibellina: Scuola Normale Superiore Pisa, 401-413.

D’Amore, L., 2007, Iscrizioni greche d'Italia, Reggio Calabria, Roma: Quasar.

Del Monaco, L., 2013, Iscrizioni greche d'Italia. Locri, Roma: Quasar.

Dickey, E., 1996, Greek Forms of Address. From Herodotus to Lucian, OUP.

Dickey, E., 2002, Latin Forms of Address. From Plautus to Apuleius, OUP.

Van Emde Boas, E., A. Rijksbaron, L. Huitink \& M. de Bakker, 2019, The Cambridge Grammar of Classical Greek, Cambridge: CUP.

Estarán, M. J., 2016, Epigrafía bilingüe del Occidente romano. El latín y las lenguas locales en las inscripciones bilingües y mixtas, Zaragoza: Prensas de la Universidad.

Franchi De Bellis, A., 2014, "Ancora sull'iscrizione di Orcevia (CIL I² 60) e sul santuario di Praeneste», Quaderni dell'Istituto di Linguistica dell'Università di Urbino 15, 67-121. 
Hofmann, J.-B., 1980, La lingua d'uso latina (trad. it. di L. Ricottilli), Bologna: Pàtron.

IMIT = Imagines Italicae A corpus of Italic Inscriptions, M. H. Crawford, W. M. Broadhead, J. P. T. Clackson, F. Santangelo, S. Thompson, M. Watmough (eds.), London: Institute of Classical Studies, 2011.

Jedrkiewicz, S., 1987, «La favola esopica nel processo di argomentazione orale fino al IV sec. a.C.», Quaderni Urbinati di Cultura Classica 27, 35-63.

KaJanto, I., 1965, The Latin cognomina, Commentationes Humanarum Litterarum XXXVI, 2, Helsinki: Societas Scientiarum Fennica.

Lattanzi, E., 1989, «I. La tegola di Pellaro (Reggio Calabria)», La Parola del Passato 44, 286-297.

Lazzarini, M. L., 1989, «II. Le iscrizioni», La Parola del Passato 44, 297-309.

LGPN = P. M. Fraser, E. A. Matthews (eds.), A Lexicon of Greek Personal Names, IIIA, Oxford: Clarendon Press, 1997.

Lilja, S., 1965, Terms of Abuse in Roman Comedy, (Annales Academiae Scientiarum Fennicae, Ser. B. Tom. 141, 3), Helsinki: Suomalainen Tiedeakatemia.

Lindner, Th., 1996, Lateinische Komposita. Ein Glossar vornehmlich zum Wortschatz der Dichtersprache, Innsbruck: Institut für Sprachwissenschaft der Universität.

Magni, E., 2016, "Notha Verba. Interferenza e mutamento attraverso le formazioni ibride latino-greco», Linguarum Varietas 5, 132-144.

Miniconi, J.-P., 1959, «Les termes d'injure dans le théatre comique», REL 36, 159-175.

Mosino, F., 1989, «III.Note linguistiche», La Parola del Passato 44, 309-310.

Mosino, F., 2002, «Profilo culturale di Reggio greca e romana», in: B. Gentili, A. Pinzone (eds.), Messina e Reggio nell'antichità: storia, società, cultura, Messina: Dipartimento di Civiltà Antiche e Moderne, Università di Messina, 311-319.

Opelt, I., 1965, Die lateinischen Schimpfwörter und verwandten sprachlichen Erscheinungen, Heidelberg: Carl Winter.

Orioles, V., 1975, «Mediazione osca e interferenze greco-latine», Incontri Linguistici 2, 177-191.

Pascucci, G., 1961, «Il nome di Pseudolus», Atene e Roma, N.S. 6, 30-34 (= Scritti scelti, I. Firenze, Università degli studi, 275-279).

Pisani, V., 1936, "Marginalia a Rohlfs, "Scavi linguistici nella Magna Grecia. Il suffisso -itano (-etano)"”, Rivista Indo-Greco-Italica 20, 107-111.

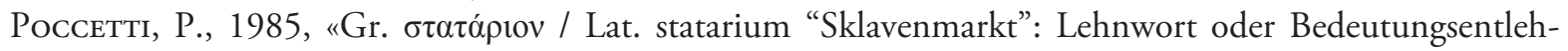
nung?», Glotta 63, 172-180.

Poccetti, P., 1988, «Lingua e cultura dei Brettii», in: P. Poccetti, Per un'identità culturale dei Brettii, a cura di Napoli: L'arte tipografica.

Poccetti, P., 2020, "La tegola di Pellaro e la tegola di Pietrabbondante. La cultura degli schiavi tra ambiente

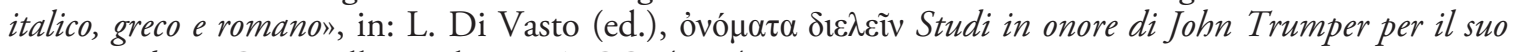
75. ${ }^{\circ}$ genetliaco, Castrovillari: Edizioni AICC, 405-455.

Probert, Ph., 2006, Ancient Greek Accentuation. Synchronic Patterns, Frequency effects, and Prehistory, Oxford: OUP.

Rohlfs, G., 1985, Antroponimia e toponomastica nelle lingue neolatine: aspetti e problemi, Tübingen: G. Narr Verlag.

Solin, H., 1982, Die griechischen Personennamen in Rom. Ein Namenbuch, Berlin, New York: De Gruyter.

Solin, H., 1971, Beiträge zur Kenntniss der griechischen Personennamen in Rom, Commentationes Humanarum Litterarum 48, Helsinki: Societas Scientiarum Fennica.

Wachter, R., 2019, Pompejanische Wandinschriften, Berlin, Boston: de Gruyter.

Zafiropoulos, Chr. A., 2001, Ethics in Aesop's fables: the Augustana collection, Leiden, Boston, Köln: Brill.

Zucchelli, B., 1969, Studi sulle formazioni latine in -lo- non diminutive e sui loro rapporti con i diminutivi, Parma: Università degli Studi. 